\title{
A Bundeswehr különleges müveleti erőinek új standard gépkarabélya, a HK416A7-es
}

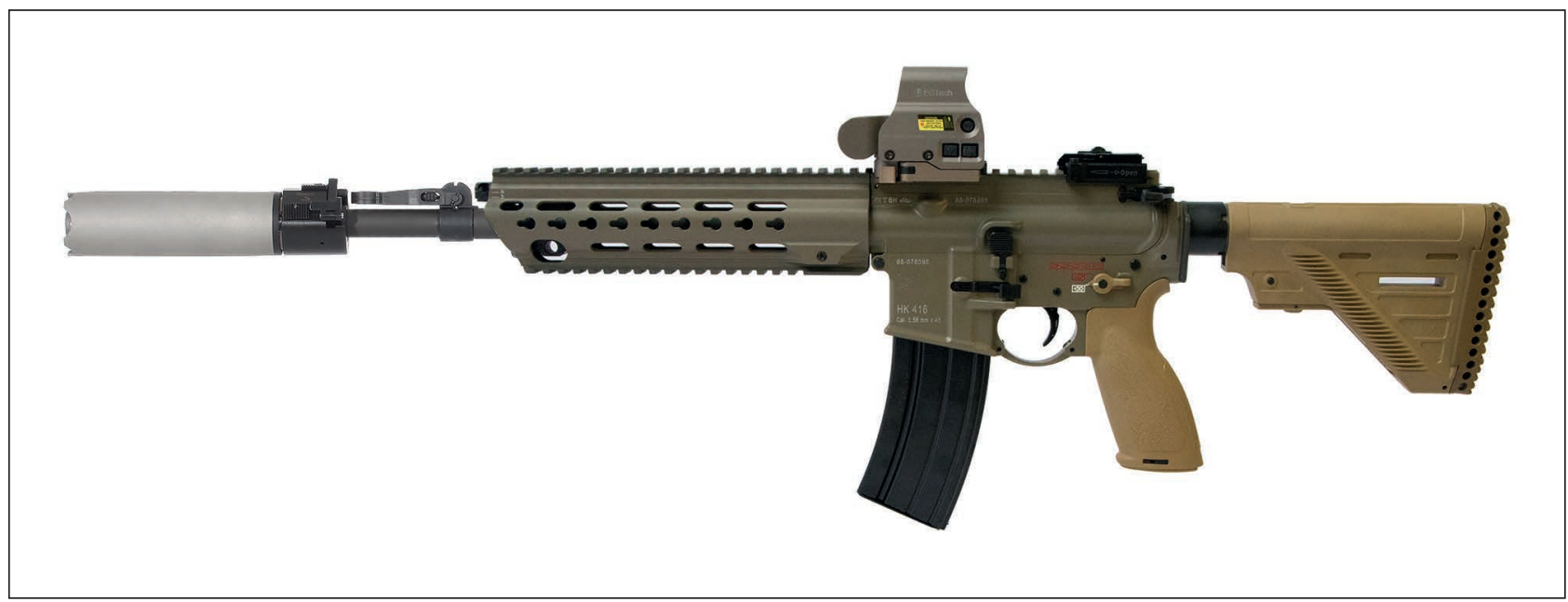

1. ábra. HK416A7-es gépkarabély Brügger \& Thomet Rotex-V hangtompítóval és EOTech optikai irányzékkal

z Oberndorf am Neckar székhelyü Heckler \& Koch fegyvergyártó cég HK416A7-es gépkarabélya nyerte a német szárazföldi- és a haditengerészeti haderőnem különleges műveleti erői (Das Kommando Spezialkräfte und des Kommandos Spezialkräfte der Marine) számára kiírt fegyvertendert, amely kiegészítőkkel együtt 1745 da-

\section{2. ábra. HK416A5-ös gépkarbély EOTech optikai irányzékkal} és GLM gránátvetővel

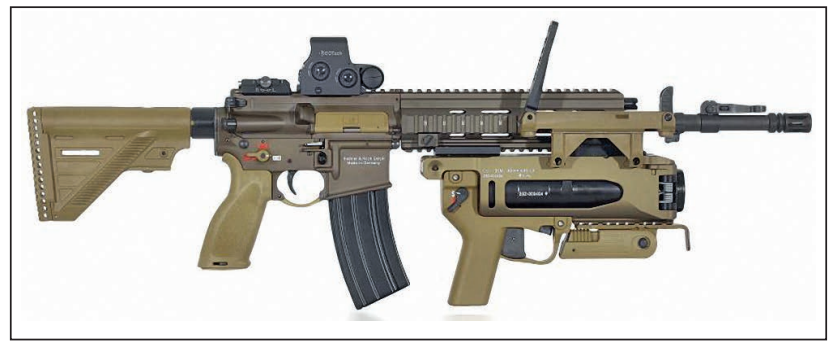

ÖSSZEFOGLALÁS: A Heckler \& Koch fegyvergyártó cég HK416A7-es gépkarabélya nyerte a német szárazföldi és a haditengerészeti haderőnem különleges múveleti erói számára 2017-ben kiírt fegyvertendert, amely kiegészítőkkel együtt 1745 darab fegyver 2020-ig történő leszállítását jelenti. Az új gépkarabély short stroke rendszerü, rövid gázdugattyú-hátrasiklásos, forgózárfejes, 5,56×45 mm NAT0-kaliberű sorozatlövő fegyver 14,5"-os csővel, FDE színű felületkezeléssel és a korábbi H\&K változatokhoz képest módosított tűzváltó karral.

KULCSSZAVAK: Különleges műveleti erők, HK416A7 gépkarabély, Picatinny szerelősín, optikai, elektrooptikai célzó berendezés, lézeres célmegjelöló, GLM/AG36 gránátvető, VTAL harcászati lézermodul, fegyverlámpa rab fegyver 2020-ig történő legyártását és leszállítását jelenti. (A Heckler \& Koch olyan lőfegyverek előállításával vált híressé, mint az MP5-ös géppisztoly, a G3-as, valamint a modernebb G36-os gépkarabély, az MP7-es önvédelmi fegyver, az USP típusú pisztolyok és a nagy pontosságú PSG1-es mesterlövész-puska.) Az új gépkarabély katalógusszáma G95 (Gewehr 95) lesz.

A tendert a Bundeswehr Technológiai és Beszerzési Hivatala (Bundesamt für Ausrüstung, Informationstechnik und Nutzung der Bundeswehr) - a Sturmgewehr der Spezialkräfte program részeként - 2017 januárjában hirdette meg a különleges műveleti erőknél rendszeresített rövid csövű G36KA1-es / A2-es / A4-es változatok leváltására. A Bundeswehr alapfegyverének számító G36-os gépkarabély pontosságával kapcsolatban ugyanis súlyos probléma vetődött fel az alkalmazói tapasztalatok, többek között az afganisztáni német misszió harcosainak tapasztalatai alapján. Mivel a fegyver műanyag tokkal készült, nagyobb lövésszámnál, amelyet egy hosszabb tűzharc is

ABSTRACT: The winner of the tender launched in 2017 for a weapon for the special operations forces of the German Army any Navy was the HK416A7 assault rifle of the Heckler \& Koch arms manufacturer; 1745 pieces of the weapon together with their accessories shall be delivered up to 2020. The $5.56 \times 45 \mathrm{~mm}$ NAT0-calibre new automatic assault rifle uses short-stroke system; it is designed with short gas piston, rotary bolt head and 14.5" long barrel; it is surface-treated to FDE-colour; its change lever is modified in comparison with the earlier H\&K variants.

KEY WORDS: Special operations forces, HK416A7 assault rifle, Picatinny rail, optical, electro-optical aiming device, laser target designator, GLM/AG36 grenade launcher, VTAL tactical laser module, flashlight

\footnotetext{
* Vincze Gyula nyá. mérnök alezredes. ORCID: 0000-0002-3732-4573
} 
előidézhet, a cső felmelegedése miatt a műanyag tokozás nem tudja a csövet az eredeti pozíciójában tartani. A cső elhúzódik, ami a találati középpont vándorlását eredményezi. Egyes források szerint ez a jelenség már 120 lövésnél is jelentkezhet, és a pontatlanság mértéke 200 m lőtávolságon akár $50 \mathrm{~cm}$ is lehet! A fegyver pontosságát a szélsőségesen meleg időjárás is ronthatja, mert ilyenkor a fegyver alkatrészeinek felmelegedése intenzívebben, lehülése pedig lassabban megy végbe.

Összesen öt fegyvergyártó cég indult a pályázaton, de közülük csak a Heckler \& Koch, a C. G. Haenel, a Rheinmetall - Steyr - Mannlicher, valamint a SIG Sauer adott le 5-5 fegyvermintát vizsgálatra a Bundeswehr meppeni fegyver- és lőszer-bevizsgáló centrumába. Az ötödik érdeklődő a Colt Canada Corporation nem nyújtott be termékmintát. Az amerikai-német SIG Sauer 2017 novemberében visszalépett a tendertől. Ahogy azt korábban feltételezni lehetett, a Heckler \& Koch nem egy standard termékkel vett részt a pályázaton, hanem a HK416-os fegyvercsalád - francia és norvég fegyveres erők által már beszerzett, és számos más ország különleges műveleti erői által már használt HK416A5-ös (G38-as) - változatát fejlesztette tovább, kifejezetten a tender céljára.

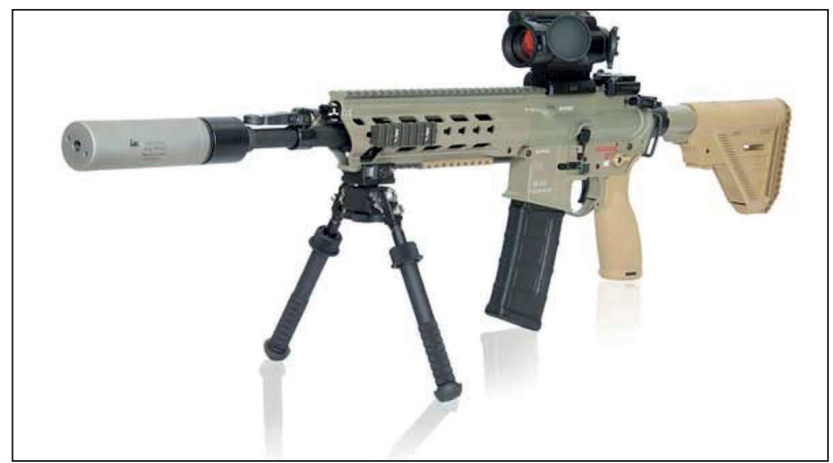

3. ábra. HK416A7-es gépkarabély Brügger \& Thomet Rotex-V hangtompítóval, kétlábú állvánnyal és EOTech optikai vöröspontos irányzékkal

A HK416A7-es egy nagy pontosságú, megbízható működésű, rendszerét tekintve gázelvételes, rövid gázdugattyúhátrasiklásos short stroke rendszerű, forgózárfejes, sorozatlövő egyéni tűzfegyver. 14,5"-os csővel, és a HK416-os korábbi változataihoz képest módosított tűzváltó karral rendelkezik, amely az 5,56×45mm NATO-kaliberü töltényt tüzeli. A short strocke rendszerből adódóan a fegyver müködése rendkívül tiszta, lőporgáz szinte egyáltalán nem jut

4. ábra. A módosított mellső markolat könnyű hozzáférést biztosít az állítható gázátömlés-szabályozóhoz

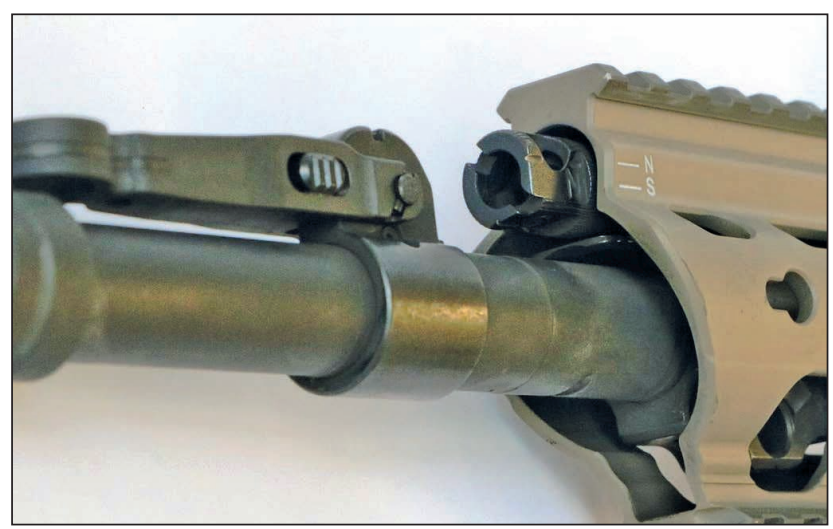

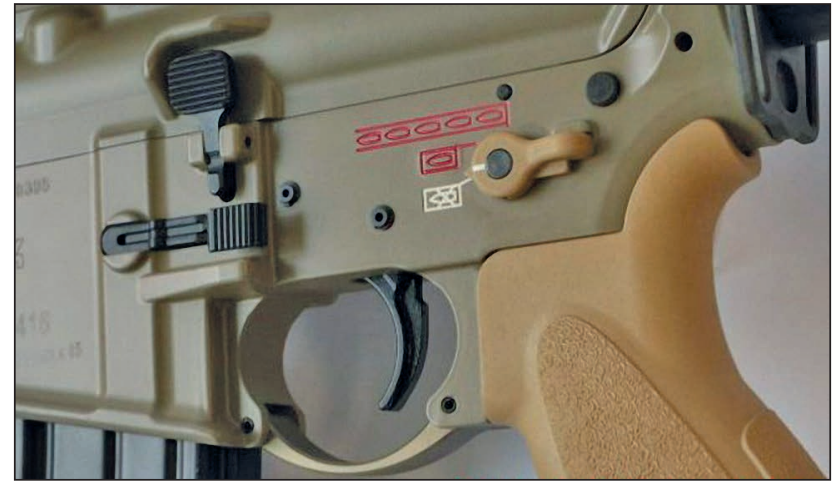

5. ábra. Az ergonomikus kialakítású, kétkezes tűzváltó kar közeli képe

hátra az elsütőszerkezethez. A gyártó állítja, hogy a fegyver akár 15000 lövés leadására is képes, és a cső ellenáll a lőporgázok korrozív savas közegének.

A HK416A5-ös (G38-as) modifikációhoz képest a HK416A7-es legszembetűnőbb módosítása a mellső agy, amely hordozza a szereléksín-rendszert és ellátja a kéz hőtől való védelmét, valamint a burkolatbevonat és az új biztonsági architektúra. Az ergonomikus kialakítású, könynyen kezelhető, kétkezes, mind a jobb-, mind a balkezes használatra alkalmas tűzváltó kart biztosított helyzetből 45 fokos lépésenként - egyeslövés-állásba $45^{\circ}$-kal, sorozatlövés-állásba $90^{\circ}-k a l$ - kell elfordítani, hogy a fegyver kibiztosított állapotba kerüljön. Ez egyébként a Sturmgewehr der Spezialkräfte projekt célkritériumát is képezte.

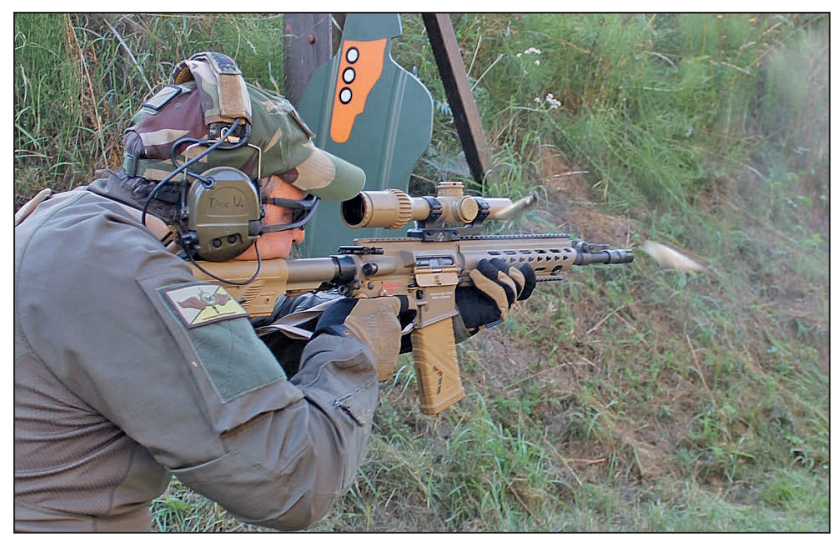

6. ábra. A HK416A7-es gépkarabély Schmidt \& Bender céltávcsővel a lőtéren

A Slim Line könnyű műanyag mellső markolatot univerzális HKey Picatinny szerelősínekkel látták el. A csőre szerelt mechanikus első irányzék lehajtható. A különféle képességnövelő kiegészítők (hangtompító, EOTech lézeres optikai irányzék, lézeres célmegjelölő, fegyverlámpa, bajonett, fegyverállvány stb.) felerősítésére szolgáló szerelősínek szerszám nélkül le- és felszerelhetők, egyszerűsítve ezzel a fegyver részleges szét- és összeszerelésének műveletét karbantartás vagy javítás során. A mellső sínrendszer 3-6-9-12 óra irányokban helyezkedik el a műanyag mellső ágyon. A szabványos sínek optikai, elektrooptikai célzó berendezéseket, lézeres célmegjelölőket, villalábat hordozhatnak. Az alsó sín alkalmas egy $40 \times 46$ mm-es Heckler \& Koch fejlesztésű, saját markolattal és célzórendszerrel ellátott, oldalra nyitható (így hosszabb lövedékkel szerelt gránátok betöltésére is alkalmas), külön fegyverként is használható GLM vagy AG36-os gránátvető csato- 
lására. A fegyver hőkezelt kerámia alapú Ceracote bevonata magas korrózió- és kopásvédelmet biztosít, ellenáll a legtöbb vegyszernek és oldószernek. Ez a modell már nem hagyományos földfekete, hanem Flat Dark Earth zöldesbarna színárnyalatú, amely nemcsak a fegyver napsugárzás általi felmelegedését csökkenti, hanem az optikai álcázást is javítja. Matt színe nem csillog, nem fénylik.

A fegyver csövén kiáramló gázok hanghatása Brügger \& Thomet Rotex-V 30 dB zajszintcsökkentő hangtompítóval minimalizálható. A módosított, szerszám nélkül is végezhető gázszabályozás lehetőséget biztosít szubszónikus lőszer használathoz is.

Az 1745 darab lézeres célmegjelölő szettre később kiírt külön pályázatot a Rheinmetall Soldier Electronics nyerte el az általa fejlesztett Variable Tactical Aiming Laser (VTAL) integrált NATO harcászati lézermodullal. Szállítása 2019 első negyedévében kezdődik. Ezt a különösen kompakt, lézertámogatott célzási technológiát kifejezetten a rövid csövű HK416A7-es gépkarabélyhoz fejlesztették ki. Robusztus kialakítása stabilitást és megbízhatóságot kölcsönöz.

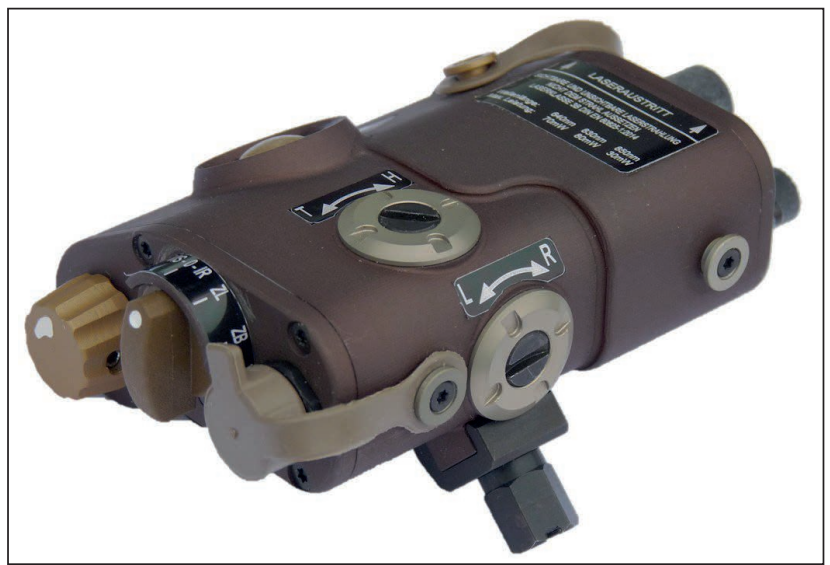

7. ábra. A Variable Tactical Aiming Laser célmegjelölő modul közeli képe

A modulhoz két különáló fegyverlámpa tartozik, egy dupla LED-fejes standard változat, valamint egy speciális - túszmentési műveleteket szolgáló - verzió. A gépkarabélyra, feladattól függően csak a VTAL-t, és csak a két fegyverlámpa egyikét szerelik fel. A fegyverhez történő rögzítést biztosítandó, a VTAL vízálló fémházát Picatinny síncsatlakozási profillal alakították ki. Mivel a modul csak körülbelül 25 mm-re emelkedik a szerelősín fölé, hagyomá-

8. ábra. Variable Tactical Aiming Laser célmegjelölő modul HK416A7-esre felszerelt állapotban

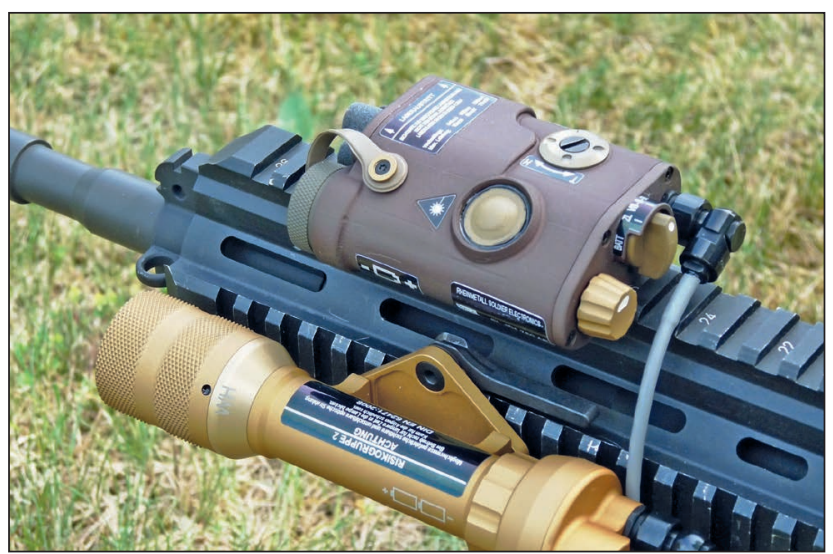

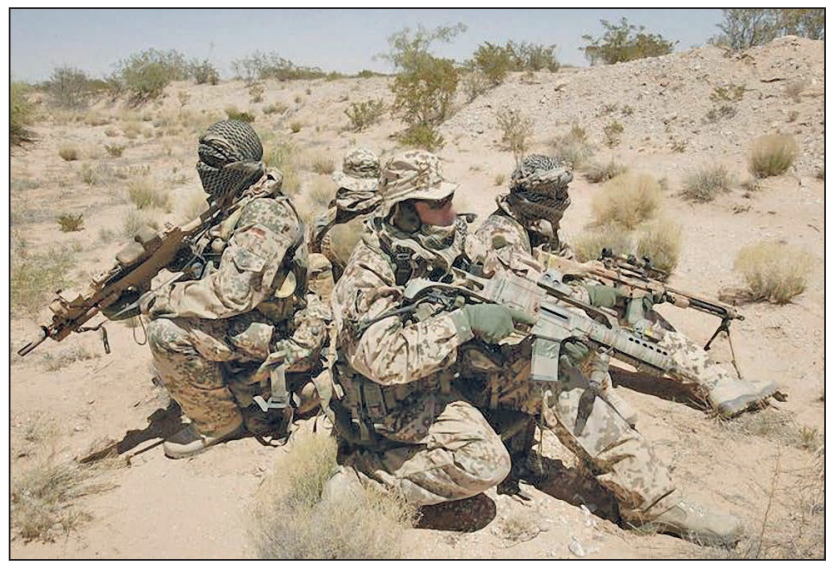

9. ábra. A Bundeswehr különleges múveleti erőinek négyfős csapata a leváltásra ítélt G36-osokkal, valahol Afganisztánban

nyos optikai célzás során nem zavar be a látótérbe. A VTAL egy rendkívül erős, látható piros pontlézerrel, egy közeli infravörös pontlézerrel, valamint egy közeli infravörös lézermegvilágítóval rendelkezik. Kompatibilis valamennyi standard éjszakai felderítő eszközzel. Gyárilag beszabályozott lézerblokk segíti a fegyver egyszerü beállítását. A kommandós katona mindkét pontlézer intenzitását színkódos kábelkapcsolóval tudja szabályozni. A célmegvilágító külön szabályozóelemmel fókuszálható. A VTAL összekapcsolható más fegyverlámpákkal, például Rheinmetall moduláris Lumenator fegyverlámpa-típusokkal is. A fénysugarak kiváló minősége és konzisztenciája képességnövelő szereppel bír.

A világ tíz legismertebb, speciálisan felkészített, különleges műveleti erői közé sorolt német elitegységeknél 2019 elejére tervezik a HK416A7-es gépkarabély bevezetését. Mivel a különleges rendeltetésű alakulatok specifikus tüzelési szokásai magas igényeket támasztanak a szolgálati fegyver funkcionalitásával és pontosságával szemben, Meppenben már 2017 végén megkezdődtek a vizsgálatra

1. táblázat. A HK416 A7-es gépkarabély főbb paraméterei

\begin{tabular}{|l|c|}
\hline Ürméret & $5,56 \mathrm{~mm}$ \\
\hline Lőszer & $5,56 \times 45 \mathrm{~mm}$ NATO \\
\hline Tárkapaciás & 30 töltény \\
\hline Múködési elv & gázdugattyús, forgózárfejes \\
\hline Csőhosszúság & $14,5 " / 368 \mathrm{~mm}$ \\
\hline Fegyverhosszúság (max.) & $893 \mathrm{~mm}$ \\
\hline Fegyverhosszúság (min.) & $797 \mathrm{~mm}$ \\
\hline Fegyverszélesség & $74 \mathrm{~mm}$ \\
\hline Tömeg - tárral & $3,69 \mathrm{~kg}$ \\
\hline Tömeg - tár nélkül & $3,49 \mathrm{~kg}$ \\
\hline Hüvelykivetés iránya & jobb \\
\hline Tüzelési mód & egyeslövés és sorozatlövés \\
\hline Szín / bevonat & Flat Dark Earth / Cerakote \\
\hline Elsütőbillentyú-húzóerő & $\sim 20 \mathrm{~N}$ \\
\hline Elméleti tűzgyorsaság & $\sim 850$ lövés/perc \\
\hline $\begin{array}{l}\text { Torkolati energia 882 m/s } \\
\text { kezdősebességnél }\end{array}$ & $1,555 \mathrm{~J}$ \\
\hline Lövedéksebesség ( $v_{0}$ ) & $882 \mathrm{~m} / \mathrm{s}$ \\
\hline
\end{tabular}


leadott első 40 tétel HK416A7 tesztjei, valamint egyidejűleg a műveleti erők elitegységeinél a harcászati szintű csapatpróbák. A rendszeresítés utáni átállás az új HK416A7-es gépkarabélyra zökkenőmentesnek ígérkezik, hiszen nyílvánvalóan nem lesz szükség a kommandós állomány G36K modellekről történő idő- és költségigényes átképzésére.

\section{FORRÁSOK}

(1) Borrud, Gabriel: Heckler \& Koch G36: the rifle held in all the wrong places. DW.com, 2015.04.13. https://p.dw.com/p/1FDOu [2019.01.11];

(2) HK416 A7 ist neues Sturmgewehr der Spezialkräfte. http://www.bundeswehr-journal.de/2017/hk416-a7-ist-neues-sturmgewehr-der-spezialkraefte/ [2019.01.11.];

(3) HK416A7 für KSK - HK (Heckler\&Koch).

https://www.all4shooters.com/de/shooting/militaer-und-behoerden/heckler-koch-hk416-ksk-bundeswehrsturmgewehr/ [2019.01.11.];

(4) HK416A7 to be called G95 by the German Special Forces https://www.thefirearmblog.com/blog/2017/10/12/hk416-a7-called-g95-german-special-forces/ [2019.01.11.];

(5) New Photos of The New HK416A7. https://www.thefirearmblog.com/blog/2017/10/18/new-photos-new-hk416a7/ [2019.01.11];

(6) G95 - Das neue Sturmgewehr Spezialkräfte. Europäische Sicherheit \& Technik November 2017;

(7) Jetzt offiziell: Spezialkräfte bekommen HK416 als neues Standardgewehr. https://augengeradeaus.net/2017/10/jetzt-offiziell-spezialkraefte-bekommen-hk416-als-neues-standardgewehr/ comment-page-1/ [2019.01.11.];

(8) Rheinmetall to Supply Laser Light Package for Bundeswehr's New Special Forces Assault Rifle. https://www.rheinmetall-defence.com/media/editor_media/rm_defence/publicrelations/pressemitteilung en/2018/2018-07-05_Rheinmetall_LLP_Special_Forces.pdf. [2019.01.11.];

(9) Germany selects G95 carbine for special forces / Jane's 360 https:/www.janes.com;

(10) Strategie \& Technik http://strategie-technik.blogspot.com;

(11) Heckler \& Koch: Product Overview https://www.heckler-koch.com;

(12) G95 for German commandos - MILMAG - The Military Magazine https://www.milmag.eu/news/view?news_id=339 [2019.01.11.];

(13) Rheinmetall to supply Laser Light Package for the new Bundeswehr's Special Forces Assault Rifle. https://www.rheinmetall-defence.com/en/rheinmetall_defence/public_relations/news/latest_news/index_17600.php [2019.01.11.];

(14) Rheinmetall "Variable Tactical Aiming Lasers" for the German Army. https://www.all4shooters.com/en/shooting/ accessories/rheinmetall-variable-tactical-aiming-lasers-for-german-army/ [2019.01.11.];

(15) German Special Forces Adopt HK416A7. https://www.monch.com/mpg/news/special-forces/2209-german-special-forces-adopt-hk416a7.html. [2019.01.11.];

(16) Gyarmati József: A nehézpuskát jellemző szempontok fontosságát kifejező súlyszámok számítása és statisztikai vizsgálata. Haditechnika 2006/2, pp. 11-16.

\section{HM ZRÍNYI TÉRKÉPÉSZETI ÉS KOMMUNIKÁCIÓS SZOLGÁLTATÓ KÖZHASZNÚ NKFT.}

Telephely: 1024 Budapest II., Sziláǵyi Erzsébet fasor 7-9.・ $₫ 1276$ Budapest 22, Pf. 85・疋 +36 (1) 336-2030・www.topomap.hu・hm.terkepeszet@topomap.hu

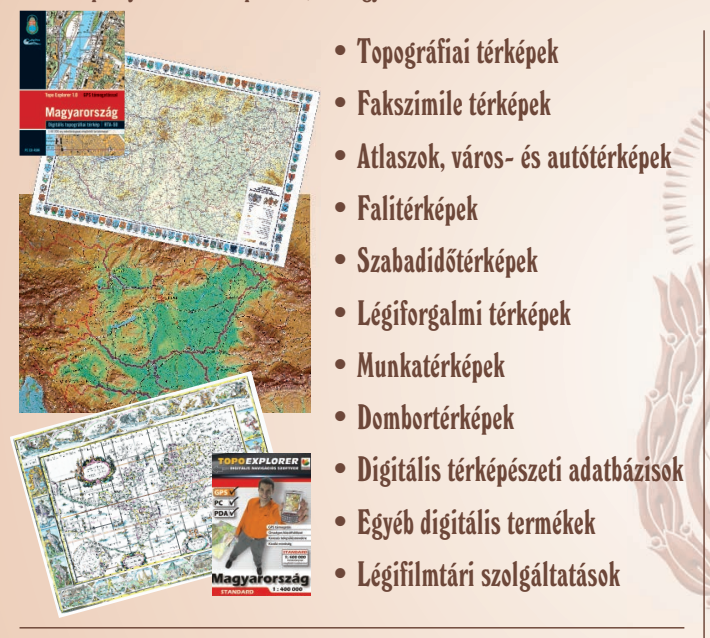

ÜGYFÉLSZOLGÁLAT ÉS TÉRKÉPBOLT:

1024 Budapest III., Fillér u. 14.

亩 +36 (1) 212-4540・ uǵffelszolgalat@topomap.hu Nyitva tartás: hétfö-péntek $9.00-15.00$
- PrePress - Nyomdai elókészítés

- szövege grafika- és képfeldolgozás, kiadványszerkesztés

- ellenőrzó nyomatok, digitális proofok előállítása

- bel-és kültéri tablók, bannerek nyomtatása

- hagyományos és elektronikus montírozás, színrebontás

- nyomóformák előállítása nyomdai filmról, illetve CTP-technológiával

- Gyorssokszorosítás

- színes és fekete-fehér másolás/nyomtatás 330 x 487 mm méretig

- Press - Nyomtatás

- ofszetnyomtatás négy-, illetve hatszínnyomó gépeken, 89 x 126 cm méretig

- PostPress - Kötészeti feldolgozás

- felületnemesítés fóliázással, laminálással 167 cm szélességig

- hajtogatás, spirálozás, sorszámozás

- összehordás, irkakészítés, ragasztókötés

- kasírozás, táblakészítés, aranyozás

- szortiment könyvkötészet

- Vákuumformázás

- vákuumformázó szerszámok, terepasztalok előállitása CNC-technológiával - vákuumformázás

$$
\text { NYOMDAI GYÁRTÁSELŐKÉSZÍTÉS: 雨 + } 36 \text { (1) 336-2035 }
$$

